\title{
Trialability and Purposefulness: Their Role Towards Google Classroom Acceptance Following Educational Policy
}

\author{
Solomon Oluyinka ${ }^{1,2}(\mathbb{D})$, Maria Cusipag ${ }^{1,3}$ \\ ${ }^{1}$ Baliuag University, Gil Carlos Street, Baliwag, Bulacan 3006, Republic of the Philippines \\ ${ }^{2}$ City College of Angeles, Arayat Boulevard, Angeles, Pampanga, Republic of the Philippines \\ ${ }^{3}$ De La Salle Araneta University, Victoneta Avenue, Potrero, Malabon City 1475, Republic of the Philippines \\ Corresponding author: Solomon Oluyinka (solomon467@gmail.com)
}

\begin{abstract}
With the COVID-19 pandemic experiences of Filipino students, the face-to-face mode of instruction in the classroom has been phased out in exchange for online learning platforms such as Google Classroom (GCR) among some K-12 learners. As advised by the Commission on Higher Education (CHED), most colleges and universities had to try available learning management systems; hence, this research study aimed to investigate the role of trialability and purposefulness towards GCR acceptance among tertiary institutions following the CHED educational policy. The researchers came up with eight hypotheses, which suggested that purposefulness may influence educational policy and acceptance of GCR. Trialability of GCR may influence educational policy and technical access. One thousand sixty-six (1066) respondents from six public higher institutions of learning were given online questionnaire; however, only 913 users were considered for the structural equation modelling and indirect effect of the suggested factors in this study. Using SmartPLS 3.0, the findings revealed that except for the hypothesis on institutional willingness $(\mathrm{p}<0.054)$, all the hypotheses were highly supported at the level of significance $p<0.00$ to $p<0.005$. Thus, this study proves that GCR is an appropriate platform for colleges and universities. Trialability and purposefulness are two great factors that contributed to the acceptance and adoption of GCR in higher institutions of learning. Future researchers are therefore encouraged to replicate this study and validate the findings since the use of GCR is relatively new among Filipino teachers and learners.
\end{abstract}

\section{Keywords}

Google classroom; Purposefulness; Educational policy; Trialability; Alternative learning platforms.

\footnotetext{
Citation: Oluyinka, S., \& Cusipag, M. (2021). Trialability and Purposefulness: Their Role Towards Google Classroom Acceptance Following Educational Policy. Acta Informatica Pragensia, 10(2), 172-191. https://doi.org/10.18267/j.aip.154 


\section{Introduction}

The COVID-19 pandemic has seriously affected the world's educational system. More than 370 million students have not attended school temporarily or permanently worldwide due to school closures imposed by governments of different countries. The outbreak has highlighted various problems involving educational opportunities as well as wider socioeconomic issues (UNESCO, 2020a).

In the Philippines, the Commission on Higher Education (CHED) issued COVID-19 Advisories 1 to 6, to prevent the spread of the coronavirus across different institutions. On 13 April 2020, Advisory 6 stated, "All CHED-recognized private higher education institutions, regardless of accreditation status, are allowed to exercise flexibility in determining the extent of adjustments to their approved academic calendar" (De Vera, 2020). Furthermore, higher education institutions (HEI) were given the option to use appropriate alternative learning platforms for their students such as electronic and non-electronic learning methods, simulations, self-directed learning activities, modules and case-based scenarios among others. Given this privilege by the CHED, the researchers attempted to explore which learning modalities had been tried by colleges and universities.

Alternative learning platforms have already been used in many parts of the world. Over 80 percent of colleges and universities in advanced territories have been actively involved in the use of e-learning to improve the education standard (Vaughan, 2010). In advanced countries, public colleges and universities are progressively adopting learning management systems and blended education (UNESCO, 2020b; Endozo \& Solomon, 2019).

With students staying at home, the face-to-face learning system is giving way to alternative learning platforms as suggested by the CHED. Many private colleges and universities in the Philippines started the school year in August, and since then, some have had the choice to try more than one learning platform including but not limited to Canvas, Messenger, Zoom and Microsoft Teams. The issue was how to choose a learning management framework for higher learning institutions that would align with the country's educational policy.

Some researchers have indeed noticed that learning management systems (LMS) are becoming more popular (Black et al., 2007; Francom et al., 2021), including Google Classroom, although it is more preferred in K-12 than at colleges (Francom et al., 2021; Fenton 2017). Hence, the researchers have tried to explore the use of Google Classroom in higher education institutions in the Philippines. Adoption of educational resources is challenging for educators especially during this pandemic period. Selecting the most suitable LMS for the institution requires careful decision-making and the necessary know-how of the gadget. Variables that act on the intent of using LMS such as Google Classroom among students in higher education (Francom et al., 2021) need to be properly considered.

In a study conducted by Sibuea (2018), a blended learning strategy in higher institutions required a learning management system (LMS) that is stable, well-proven and accessible to both teachers and students. He made use of Google Classroom due to its cross-platform presence, stability and ease-of-use. While Google Classroom had been used by many K-12 learners in Indonesia, his participants were university students from Pengantar Linguistik Umum who used it for video podcasts, online quizzes and assignments. His findings showed that Google Classroom is an acceptable LMS for blended learning at their university because it is user-friendly and appropriate for higher education institutions.

Francom et al. (2021) compared Google Classroom and D2L Brightspace using the Technology Acceptance Model among their K-12 participants. Their participants had already been using D2L Brightspace prior to their survey, which could be a reason why they preferred D2L Brightspace to Google Classroom. They concluded that Google Classroom may be of help to the personnel of other higher education institutions who have not used Google Classroom yet and are still trying to consider adopting the new and free Google Classroom LMS. Thus, there is a need to review related articles in order to identify the purposes of public 
colleges using a specific LMS in accordance with the educational policy during the outbreak of COVID19. Hopefully, the findings of this study will be valuable additions to the technology acceptance database of attributes and practices, as well as useful to practitioners.

\section{Literature Review}

This section contains reviews of related articles about the acceptability of technology and the deployment of certain LMS by universities and colleges.

\subsection{Studies on Google Classroom as a learning management system (LMS)}

Learning management systems (LMS) are extensive platforms that respond to the concerns of academic learning and management training by providing different online learning courses for work and encouraging learners to improve their performance. This is an alternative for those who want to move from face-to-face learning to online learning (Oluyinka et al., 2015). The LMS enables learners to access interactive lessons, exchange ideas with their teachers, compile course materials, take online exams and submit classroom assignments (Nielson, 2017; Solomon et al., 2014).

According to a recent study, the top ten free learning management systems are widely used by universities and colleges, and Google Classroom took first position among the 10 best free learning management systems listed (https://www.g2.com/categories/learning-management-system-lms). Between the last three months of 2019 and the first three months of 2020, Google educational applications saw a 90-percent increase in weekly downloads worldwide (Dian, 2020). Google Apps For Education now has over 50 million users, and over 10 million educators and students worldwide are actively using Google Classrooms to teach and learn together, save time and stay organized (Cinthya, 2021).

Learning management systems, such as Google Classroom, were created with the goal of enhancing learning skills and promoting self-esteem in both teaching and learning (Kaewsaiha, 2019). They are mostly considered for online learning, but they can also be used for a variety of other purposes, such as serving as a trial portal for online instructional content in asynchronous and synchronous sessions (Singh et al., 2010). In addition, to justify the purpose of using a particular LMS, investigation must be done. Based on the practice of many consumers, any gadget they buy or intend to use has to be studied or tried before it is purchased. This justifies a glance at whether Google Classroom may be a viable platform for higher education institutions during the pandemic stage.

\subsection{Technology factors and Google Classroom acceptance}

Google Classroom (GCR) is a reasonably free learning management program that started in the year 2014. It takes into account the achievement of specific objectives such as the simplification of student-teacher interaction and the convenience with which assignments are distributed and graded. It offers an opportunity to complete the process of teaching and learning. Its features are appropriate for both learners and teachers. It gives students a flow of information and builds up academic research (Lai \& Bower, 2019; Sukmawati \& Nensia, 2019).

Interestingly, Google Classroom can improve academic learning skills (Rahmad et al., 2019). It is a selfdirected learning tool that provides self-satisfaction for the users. Additionally, as an e-learning technology, it lays the groundwork for improved online courses and academic support services that eventually encourage students to excel in a digital context (Perdana et al., 2020; De Campos et al., 2019). This indicates that GCR can be combined with other applications, e.g., for knowledge discovery, to maximize the practical use potential.

Kumar et al. (2020) investigated how higher education institutions accept Google Classroom. Their study aimed primarily to explore the use of GCR from the students' perspective, and complementing it with the 
instructors' perspective. As defended by Washington (2019), the awareness and complexities encountered in using GCR are explored by obtaining feedback from the views and opinions of current users as main users of the online system (Bayarmaa \& Lee, 2018; Albashtawi \& Al Bataineh, 2020).

\subsection{Theoretical framework}

Researchers employ a vast number of theories and models for the integration of information technologies, and each model has several versions and expansions. Following a literature review, one conclusion emerges: the theoretical model must be modified as a function of the description of the features of the topic under investigation.

This study was anchored in the Technology Acceptance Model (TAM) of Davies (1989, in O'Bannon \& Thomas, 2015; Charnes \& Boot, 2016; Macedo, 2017; Lazar et al., 2020). It is an information systems theory that models how users come to accept and use a new technology based on customer attitudes. There are two factors that can influence a person's intention to adopt a new technology: perceived ease of use and perceived usefulness (purposefulness). Following this notion, an extended TAM was considered for this study to measure levels of technology adoption across higher education institutions in a new normal learning context.

Therefore, the three main factors, namely perceived ease of use, perceived usefulness (purposefulness) and intention to use (GCR), were considered as the input parameters for this study. They are the result of the action of several external variables describing the educational decision process under the influence of some moderating factors such as trialability (Roger, 2003). To establish the best external variables for this study's model, some important aspects of the technology, organization and environment factors such as institutional willingness and educational policy found relevant in terms of top management support and technology readiness (Gutierrez et al., 2015) were considered.

\section{Methodology}

Based on a methodological point of view, the following were considered:

\subsection{Research design}

An adaptation of the TAM was utilized in this study to evaluate seven constructs related to the usage of Google Classroom as a learning resource during the COVID-19 epidemic in the Philippines. The aim of this expansion of the basic TAM was to identify and describe as clearly and properly as possible the factors that influence users and educational policy decision makers in public higher education institutions about the usage of Google Classroom.

The current study has expanded the factors utilized to analyse users' experience within the concept of technology acceptance and utilization. As a result, one inquiry model was constructed to interpret the factors that may influence educational policy decisions in such circumstances as a dependent variable. On the other hand, perceived purposefulness, expected attitudes, institutional willingness and perceived technological access are suggested to have an impact on Google Classroom usage. The studies also conceptualized the moderating effects of trial run (trialability), educational policy and usage of Google Classroom.

\subsection{Instrument development}

A variety of methods were used to create a research instrument that assesses the role of trialability and purposefulness in the relationship between educational policy and Google Classroom acceptance at public universities and colleges in the Philippines. A questionnaire was used as a research instrument in this study. 
A collection of LMS-related questions was utilized to create a consistent and valid version of the research instrument. The recommended instrument was created using relevant tools published in the literature. A 4-point Likert scale ranging from 1, which strongly disagrees, to 4, which strongly agrees, was adopted (Safsouf et al., 2020; Ayodele et al., 2016; Oluyinka et al., 2013; Ajagbe et al., 2014; Ayodele et al., 2018). This was made available as an online survey questionnaire. However, face-to-face interviews were omitted due to the restrictions brought about by the COVID-19 crisis.

As a result, the proposed items were in relation to the theoretical framework and the items were evaluated to ensure their validity and reliability. The validity of the measuring scale was assessed using PLS Algorithm quality criteria, which included construct reliability and discriminants. Structural equation modelling (SEM) and path analyses were used to investigate the relationships between variables. The same multivariate analysis was used to assess the replication generalizability of the measurement scale (SEM and path analyses).

A total of 913 questionnaires were considered based on the Google questionnaire link floated from March to July 2020 to six selected institutions, namely, City College of Angeles, Don Honorio Ventura State University, Mabalacat City College, Bulacan State University, Gordon College and Pampanga State University. After having obtained approval from the presidents and vice-presidents of public HEI to conduct an online survey, learners and educators assisted in the online distribution of the questionnaires through their social media contacts, professional means, faculty associations, and student council contacts.

\subsection{Dimension of measures}

\subsubsection{Expected attitude with use of Google Classroom}

The original TAM components were interchanged and expanded with associated external variables in this study. Google Classroom incorporates Google Apps for education, such as Google Docs, Slides and others, as well as additional grading tools based on a literature study. The framework was designed with the goal of generating the desired sentiments about Google Classroom use. The operational definition of this factor comprises the digital technologies utilized as educational materials suited for learning. In this example, the measure was selected to assess users' predicted attitudes towards Google Classroom usage. The items emphasize the users' attitudes in terms of engagement, attractiveness and relevance to overcoming teaching and learning issues while using GCR.

\subsubsection{Institutional willingness vis-à-vis educational policy}

This concept is regarded as an integrated variable and in this study, institutional willingness is defined as the school's acceptance to choose and use digital learning resources in accordance with the policy of the educational advisory board. The purpose is to look into how higher education institutions have been experimenting with Google Classroom as a learning management system (LMS). The construct highlights the institution's mission and commitment in using technology as well as receiving prompt assistance and incentives.

\subsubsection{Perceived purposefulness vis-à-vis educational policy and use of Google Classroom}

Adoption of LMS tools is largely measured by the purpose of improving educational quality, boosting user knowledge sharing or expanding users' intents if utilized. In order to investigate the perceived usefulness of using Google Classroom in relation to educational policy, four items were chosen. One of the perceived purposes was to address the interruption of the face-to-face education system; the LMS was adopted for the purpose of completing academic duties conveniently and on time. 


\subsubsection{Role of trial run as moderator among technical access, educational policy and use of Google Classroom}

According to Roger (2003), trialability is the extent to which an innovation can be tested on a limited basis. New innovations require a time investment. A trial run used as a moderator among technical access, educational policy and use of Google classroom was suggested as another dimension in this study. The degree to which an individual perceives that a technological infrastructure exists to enable use of the system is referred to as technical access; in this situation, perceived technical access represents objective factors (connectivity, gadgets, power supply) that can aid in the execution of educational policies related to the construct of use of Google Classroom assumed in this study.

The construction of trial runs is performed because users would like to try a gadget first before deciding whether to purchase it, the gadget is adequately available for users if recommended, there is a chance to have a demo trial, they experience the necessity of using it and make a trial to confirm its relevance to academic activities. The technical construction emphasizes that users have access to a computer/laptop/phone with an internet connection at home, a dependable internet browser app, connectivity with neighbours/family at home, access to a printer and others.

Furthermore, the development of the Google Classroom construct was based on the following: understanding the cost implications of using it, providing timely feedback, being able to blend it with traditional learning systems, organizing assignments and creating a paperless study environment, improving communication skills for low self-esteem users, encouraging collaboration among faculty, students and management, and being equipped with the same features as other learning management systems.

\subsection{Questionnaire}

This study used or created items to explore the attitudes that are expected when using Google Classroom (Safsouf et al., 2020; Rahmad et al., 2019). Items that assess perceived purposefulness (usefulness) have been generated in similar research (Ivanovic \& Milenkovski, 2019; Yalung et al., 2020; Roger, 2003). Meanwhile, elements to assess institutional willingness have been observed to be linked (Tom et al., 2019; Abazi-Bexheti et al., 2012; Jajaga \& Abazi-Alili, 2018; Toquero, 2020).

Perceived technical access was found to be related to the facilitation conditions for user acceptance of information technology established by Venkatesh et al. (2003). Items to measure perceived technical access construct in this study have also been identified in other related studies (Siswanto et al., 2018; Duan et al., 2010).

Trialability, on the other hand, represents the extent to which an innovation may be assessed. In this study, items used to assess trial runs (trialability) have been shown to be consistent (Rogers, 2004; Waheed et al., 2015; Pandl et al., 2021). The educational policy construct was assessed using four linked items derived from other studies (Al-Maroof \& Al-Emran, 2018; Webster et al., 2013).

Google Classroom (GCR), the main subject of this study, is a free application that provides timely feedback for a face-to-face learning system; it is suitable for organizing assignments and creating paperless learning. With GCR, teaching and learning take place in a simple setting. It enhances communication skills for low self-esteem users, encourages collaboration among faculty, students and management, and is recommended as a learning management system due to its features. Five foreign education experts from New Zealand, USA, Malaysia, Turkey and Nigeria, as well as two internal experts from Baliuag University and De La Salle Araneta University in the Philippines, were requested to validate the questionnaire. Some items were revised and modified in response to the experts' observations. After the second review, the final draft of the questionnaire retained 33 items, all of which were answered on a four-point Likert scale 
ranging from 1 (strongly disagree) to 4 (strongly agree). Nonetheless, for the sake of ethics, consent and openness, a Google Form survey link is included herein to solicit responses (see Data Availability Section).

\subsection{Analysis methods}

This study is a quantitative study using SmartPLS 3.0 in order to get the desired results (Sarstedt \& Cheah, 2019; Yalung et al., 2020; Roman, 2020; Pangilinan et al., 2020). SmartPLS 3.0 makes simple group analysis easier to execute than other frequently used packages (e.g., IBM SPSS AMOS). WarpPLS 6.0 and SPSS Macro can also be good tools for moderation analysis but they have no graphical output (Ezekiel \& Oluyinka, 2020; Memon et al., 2017; Oluyinka, 2016; Oluyinka et al., 2013). One aspect of this study is to describe the moderating effect of trialability in the relationship between educational policy and GCR. However, steps involved in analysing a moderating effect vary based on the statistical package and the approach used. It is almost out of scope of this study to explain the analytical steps of each approach using different packages.

Factor analysis, based on maximum likelihood estimate (Ringle et al., 2018), was performed using the SmartPLS 3.0 statistics software to describe the experimental data. In addition, factor analysis was used to assess the reliability and validity of the dimensions (Hair et al., 2017). Multiple criteria, as proposed in the literature, were utilized to explain the data quality and the measurement model (Hair et al., 2019).

Cronbach's alpha, rho-A, composite reliability (CR), and average variance extracted (AVE) were the construct reliability and validity quality criteria utilized (Memon et al., 2019; Oluyinka et al., 2021). Cronbach's alpha, rho-A, CR, and AVE were all acceptable values of 0.7 or above (Oluyinka et al., 2021; Memon et al., 2019; Roman et al., 2020).

The extent of the linkages between latent components impacted on the discriminant validity of the variables (Lee, 2019; Leuteritz et al., 2019). Fornell and Larcker (1981) define discriminant validity as "each concept's AVE being greater than the construct's squared correlation with any other construct". For assessing discriminant validity, the square root of the AVE of each variable was compared to the inter-factor correlations (Ramírez-Correa et al., 2015).

Memon et al. (2019) stated that a moderator variable (M) may or may not have an effect on the dependent variable $(Y)$. As a result, a meaningful relationship between the moderating effect $(Z)$ and the dependent variable can be used to determine if there is a moderating effect $(Y)$. In addition, researchers must measure and record the impact size ( $f 2)$ as a function of the moderation. The route analysis and structure modelling of the current study involve testing the links between the dimensions to use the specified LMS. This was formed using a structural equation modelling technique to reveal the moderating effect of trial runs as well as the influence of perceived purposefulness in the relationship between educational policy and use of Google Classroom.

The design and assessment of a measurement model within the context of the SEM structural equation modelling improves factor estimate accuracy and the validity of research results (Calma \& Oluyinka, 2020; Hair et al., 2019). Path analysis was utilized to discover factors that influence dependent variables such as educational policy, perceived technical access and utilization of Google Classroom (Lai \& Bower, 2019; Sukmawati \& Nensia, 2019). Therefore, the measures were subsequently subjected to a path analytic model to validate the hypothesized relationships among factors. Accordingly, the method allowed the study to quantify and compare the effects of external variables on each of the internal effects of the variables.

\subsection{Research hypotheses}

The study's primary goal was to validate the impact of perceived purposefulness and the influence of trial runs on Google Classroom usage in line with educational policy. In addition, the major variables 
impacting on the acceptability of the specified learning management system in public higher education institutions were investigated, and the links among the various constructions were tested. To achieve the study objective, eight unique research hypotheses were proposed.

\subsubsection{Hypothetical statements}

Some foreign studies have validated the acceptance of GCR among students (Robinson, 2017). In this study, the researchers attempted to investigate the role of trialability and purposefulness towards Google Classroom acceptance following the CHED educational policy. Thus, hypotheses were developed as shown in the following paragraphs.

H1: Attitude may influence GCR acceptance: Attitude towards the use of GCR was supported in the research study. Accordingly, students' impressions about GCR may be influenced by teachers' attitudes (Safsouf et al., 2020; Rahmad et al., 2019). In addition, Pan's (2020) study affirmed that attitude is one of the factors to illustrate the relationship between students' perceptions of technology environments and self-directed learning. Moreover, Abd Manan and Hanafi (2019) backed up their views on the use of GCR in a study where Google Classroom is adopted and used in Islamic education. Learners have a positive attitude towards technology acceptance according to some studies (Mousa et al., 2020; Kanwal \& Rehman, 2017). Supportively, Hussein (2017) also affirmed that attitude plays a significant role in persuading students to use e-learning. Furthermore, several studies on attitudes and intentions to use e-learning have supported this conclusion. According to Altawallbeh et al. (2015) and Granić \& Marangunić (2019), attitude is a critical factor in determining whether to use technology or not. Thus, it is assumed that attitude may influence GCR acceptance (H1).

H2-3: Institutional willingness and educational policy lead to GCR acceptance: Abazi-Bexheti et al. (2018) asserted that LMS is considered a key technology to support HEI learning. The study further acknowledged that almost every institution varies in terms of experience in using the system. Toquero (2020) asserted that quality higher education is considered a crucial factor to produce competent professionals that would build a strong nation and the best way to get along with global competition (Ajagbe et al., 2011; Al-Maroof \& Al-Emran, 2018). The study concluded that interactive teaching materials from GCR could be used to achieve the institution's educational goals. Therefore, this study assumes that educational policy may influence acceptance of GCR (H2) and that institutional willingness among the HEI may influence educational policy to accept GCR (H3).

H4: Moderating effects of trialability: Moderating variables are introduced when there is an unexpectedly weak or inconsistent relation between an antecedent (independent variable) and an outcome across studies (Baron \& Kenny, 1986; Frazier et al., 2004). Andersson et al. (2014) affirmed that moderating variables can also be tested for the purpose of obtaining new theoretical insights. According to Gardner et al. (2017) and Froese et al. (2018), if $M$ moderates the relationship between the variable $X$ and the variable $Y$, this may not necessarily be a good hypothesis. Thus, the purpose of this study was to hypothesize a moderating role of trialability in the relationship between technical access and educational advisory (Aguinis et al., 2017; Memon et al., 2019). Trialability paths are being considered because the Philippine educational advisory allows colleges and universities to select the LMS of their choice. Furthermore, Kousar et al. (2017) emphasized that state intervention considerably moderates the relationship among difficulty, relative benefits, trialability and technology adoption. Ngafeeson and Sun's (2015) study on the moderating effects of system exposure indicated that the implemented program has a moderating effect on the electronic textbook adoption behaviour of users. It was hypothesized that device exposure moderated the impact of two variables on behavioural intent: ease of use and subjective norm (Vafaei-Zadeh et al., 2018; Shiau \& Chau, 2016). Considering these facts, it is thus hypothesized that trialability of GCR may have a moderating effect on educational policy (H4). 
H5-H6: Perceived purposefulness and educational policy lead to the use of Google Classroom: Ewing and Cooper (2021) stated that the pandemic has accelerated the implementation of emerging technologies in classrooms. Ivanovic and Milenkovski (2019) also stressed that the advancement of technology is accelerating teaching and learning, providing a faster way to transfer knowledge, values and skills. New ways of gaining different competencies are rapidly being introduced as today's generation requires the use and support of the latest types of modern IT solutions. The younger generations are getting interested in the online world of the internet and other computer-based technologies. Technical benefits of cost savings, rapid growth and development and faster processes have been achieved with the use of many innovations. Perceived usefulness strongly influenced peoples' intentions (Davis et al., 1989). Therefore, it is hypothesized that purposefulness may influence educational policy (H5) and that purposefulness may influence Google Classroom acceptance (H6).

H7-8: Trialability and technology acceptance decision: Trialability reflects the extent to which an invention may be evaluated. It eliminates confusion for those who learn by doing and for those who restrict themselves before making any commitment (Rogers, 2004; Waheed et al., 2015). Innovations that allow trial periods attract more users and positively influence their adoption (Oluyinka et al., 2015; Pandl et al., 2021). The belief of teachers and students that GCR can be tested before it is decided for use and approved by the other stakeholders is referred to as trialability in this study. In a report on e-learning adoption in China, Duan et al. (2010) found that only perceived compatibility and trialability have a substantial impact on e-learning adoption intention. Rai et al. (2020) and Siswanto et al. (2018) asserted that technical facility access corresponds to the external factors that facilitate an operation. This includes hardware availability, software, quick internet connectivity and technical support, among others, which facilitate users' accessing and using of technology (Webster et al., 2013) suggested that educational policy could be influenced by the element of innovation diffusion. Thus, this study expects that trialability of GCR may influence educational policy (H7) and that trialability of GCR may influence technical access (H8).

Moreover, Figure 1 shows the hypothetical conceptual framework of the study.

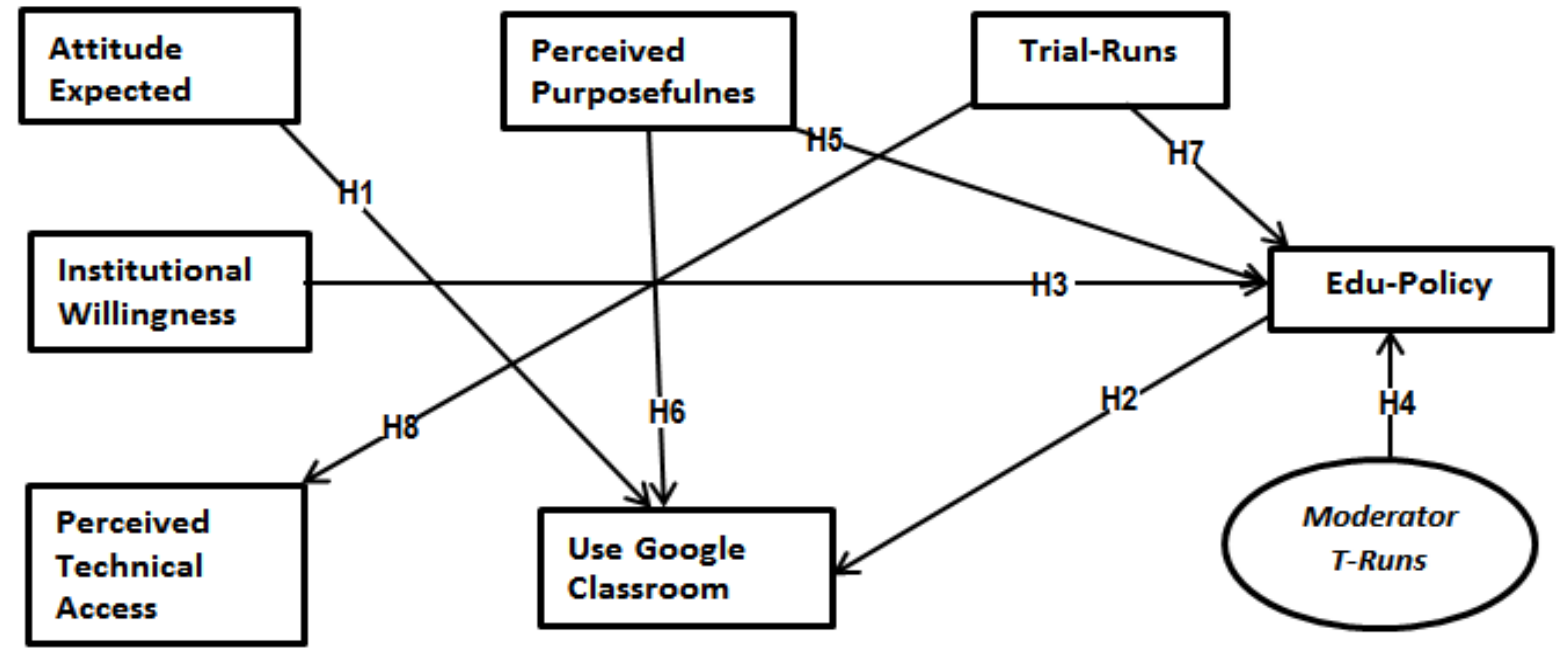

Figure 1. Conceptual framework of the study.

\section{Analysis and Results}

\subsection{Participants' demographic information}

The study included students ( $82 \%$ of the total) and teachers (18\% of the total). The age groups were 18 to 25 years old $(71 \%)$ and 26 to 33 years old (16\% of the total). The study is dominated by females (51\% of total); and males make up only $41 \%$ of total, while $8 \%$ chose not to indicate. It is widely predicted that the 
mathematical expressions of teachers and students would be at least at a ratio of 1 to 3 (Dana \& YendolHoppey, 2019). Thus, the present research had a total sample size of 913 participants, which can be viewed as adequate (Türel, 2011).

\subsection{Reliability and validity analysis}

A total of 33 measures were subjected to a composite reliability test, which confirmed the discriminant validity of the constructs between 0.86 to 0.97 based on the average correlation above 0.5 (Sarstedt et al., 2019; Oluyinka et al., 2018). Nevertheless, the coefficient for the moderator constructs indicated 1.000 as expected (Jiménez-Carvelo, 2019). An initial sample of 913 was bootstrapped to 5000 samples in the SmartPLS 3.0 subsample setting. A $p$-value of less than 0.05 was adopted, and variance explained was likewise adopted to predict the good fit of the model (Oluyinka et al., 2018; Dayrit \& Lacap, 2020; Calma \& Oluyinka, 2020; Oluyinka et al., 2021). This study further examined the validity of the instruments using discriminant tests after the justification of Cronbach's alpha.

Furthermore, the discriminant validity of the constructs justified the recommended average correlation above 0.5 (Sarstedt et al., 2019; Oluyinka et al., 2018). As a result, considerable reliability and internal consistency were obtained among the items in the factor loading, as shown in Table 1.

Table 1. Measurement items retained.

\begin{tabular}{|c|c|c|c|c|}
\hline \multicolumn{5}{|c|}{ Codes: construct reliability and validity } \\
\hline Retained items & $\begin{array}{l}\text { Factor } \\
\text { loading }\end{array}$ & Alpha & $\begin{array}{l}\text { Composite } \\
\text { reliability }\end{array}$ & $\begin{array}{l}\text { Average } \\
\text { variance } \\
\text { extracted }\end{array}$ \\
\hline \multicolumn{5}{|l|}{ Attitude } \\
\hline $\begin{array}{l}\text { ATT1: I can use GCR to engage in the teaching and learning } \\
\text { process. }\end{array}$ & .834 & \multirow{3}{*}{.878} & & \multirow{3}{*}{.779} \\
\hline $\begin{array}{l}\text { ATT2 : Using technology is a pleasant idea during the } \\
\text { COVID- } 19 \text { pandemic. }\end{array}$ & .920 & & .879 & \\
\hline ATT3: I think using Google Classroom is an appealing idea. & .892 & & & \\
\hline \multicolumn{5}{|l|}{ Educational policy } \\
\hline $\begin{array}{l}\text { EP1: I think providing distance learning during pandemic by } \\
\text { the HEI is in accordance with CHED's advisory or directive. }\end{array}$ & .712 & \multirow{3}{*}{.897} & & \multirow{3}{*}{.605} \\
\hline $\begin{array}{l}\text { EP2 : CHED's advisory supported the use of learning } \\
\text { management system at home with parental guidance. }\end{array}$ & .794 & & .799 & \\
\hline $\begin{array}{l}\text { EP3: I think the government will support blended learning } \\
\text { using GCR. }\end{array}$ & .824 & & & \\
\hline \multicolumn{5}{|l|}{ Google Classroom } \\
\hline $\begin{array}{l}\text { GCR1: Google Classroom is a free application for users to an } \\
\text { extent. }\end{array}$ & .856 & \multirow{5}{*}{.845} & & \multirow{5}{*}{.695} \\
\hline $\begin{array}{l}\text { GCR2: It provides timely feedback and could be blended with } \\
\text { the face-to-face learning system. }\end{array}$ & .861 & & & \\
\hline $\begin{array}{l}\text { GCR5: I feel the application may enhance communication } \\
\text { skills for low self-esteem users. }\end{array}$ & .787 & & .940 & \\
\hline $\begin{array}{l}\text { GCR 6: I think it encourages collaboration among faculty, } \\
\text { students and management. }\end{array}$ & .876 & & & \\
\hline $\begin{array}{l}\text { GCR7 : I feel GCR is equipped with the same features as other } \\
\text { learning management systems. }\end{array}$ & .784 & & & \\
\hline \multicolumn{5}{|l|}{ Institutional willingness } \\
\hline $\begin{array}{l}\text { IW1: Use of a learning management system is in line with the } \\
\text { institution's mission. }\end{array}$ & .883 & \multirow{3}{*}{.879} & & \multirow{3}{*}{.732} \\
\hline $\begin{array}{l}\text { IW2 : My school is committed to using technology in } \\
\text { achieving academic objectives beyond just education. }\end{array}$ & .896 & & .911 & \\
\hline $\begin{array}{l}\text { IW4 : My institution encourages the use of a non-traditional } \\
\text { or technology-based teaching and learning system. }\end{array}$ & .740 & & & \\
\hline
\end{tabular}




\begin{tabular}{|c|c|c|c|c|}
\hline \multicolumn{5}{|c|}{ Codes: construct reliability and validity } \\
\hline Retained items & $\begin{array}{l}\text { Factor } \\
\text { loading }\end{array}$ & Alpha & $\begin{array}{l}\text { Composite } \\
\text { reliability }\end{array}$ & $\begin{array}{l}\text { Average } \\
\text { variance } \\
\text { extracted }\end{array}$ \\
\hline \multicolumn{5}{|l|}{ Perceived purposefulness } \\
\hline $\begin{array}{l}\text { P P1: I think Google Classroom is an alternative to disrupted } \\
\text { face-to- face learning system. }\end{array}$ & .869 & \multirow{3}{*}{.848} & & \multirow{3}{*}{.686} \\
\hline $\begin{array}{l}\text { PP2: The technology is useful to complete my academic } \\
\text { activities conveniently. }\end{array}$ & .831 & & .919 & \\
\hline $\begin{array}{l}\text { PP3: The application is efficiently useful and serves its } \\
\text { purpose in terms of time management. }\end{array}$ & .782 & & & \\
\hline \multicolumn{5}{|l|}{ Technical access } \\
\hline $\begin{array}{l}\text { PTA2: I have access to a computer/laptop/phone with an } \\
\text { internet connection at home. }\end{array}$ & .822 & \multirow{3}{*}{.828} & & \multirow{3}{*}{.694} \\
\hline $\begin{array}{l}\text { PTA3:I have a dependable computer/laptop/phone with a } \\
\text { dependable browser. }\end{array}$ & .828 & & .906 & \\
\hline $\begin{array}{l}\text { PTA5 : I can easily connect my computer/laptop/phone } \\
\text { monitor, printer and others. }\end{array}$ & .849 & & & \\
\hline \multicolumn{5}{|l|}{ Trial runs (TRUNS) } \\
\hline $\begin{array}{l}\text { TRU2: I think the application is adequately available for me to } \\
\text { test-run if recommended. }\end{array}$ & .893 & \multirow{3}{*}{.912} & & \multirow{4}{*}{.823} \\
\hline $\begin{array}{l}\text { TRU3: I would like to base my decision to use GCR as a result } \\
\text { of the demo trial. }\end{array}$ & .922 & & & \\
\hline $\begin{array}{l}\text { TRU5: I would like to test-run GCR as a learning } \\
\text { management system with my academic activities. }\end{array}$ & .834 & & .908 & \\
\hline Moderator TRUNS $\rightarrow$ Educational policy & .974 & 1.000 & 1.000 & \\
\hline
\end{tabular}

A total of 23 out of 33 items were retained for the structural equation modelling. On the Google Classroom measures, the measurements for reliability and validity examinations suggested, respectively, the deletion of two items: "The application organizes assignments and creates a paperless study environment" (GCR3) and "I guess teaching and learning can take place online with the use of the application" (GCR4) and one item: "I think my teaching methods and learning goals are being addressed in GCR" (ATT4).

The investigation also advised the removal of "I believe the government may include incentives for technology users in the future" (EP 4) from the educational policy measures. Similarly, "The school gives chances and prompt help to instructors" (IW3) was suggested as one of the institutional policy measures to be removed. This was on perceived purposefulness, which is why "I believe that during this time of pandemic, the purpose of LMS such as GCR is timely" ( $P P 4)$ was eliminated from the modelling. Moreover, the examination suggested two items for deletion: "I have a smartphone with an installed necessary application for online teaching and learning" (PTA1) and "I am willing to seek connectivity with neighbours/family at home" (PTA4) on the basis of perceived technical access. Likewise, two items were removed: "I think I would like to try them first before deciding to use GCR" (TRU1) and "I think before deciding on using GCR or not, I want to experience the necessity of using it" (TRU4).

\subsection{Measurement validity}

The convergent and discriminant validity coefficients corresponding to the considered total sample were computed. The calculated values of convergent and discriminant validity coefficients exceeded the threshold values (Hair et al., 2012). The heterotrait-monotrait ratio of correlations (HTMT) also found a supported range of 0.164 to 0.794 , all below 0.85 (Ringle et al., 2018), as shown in Figure 2. 


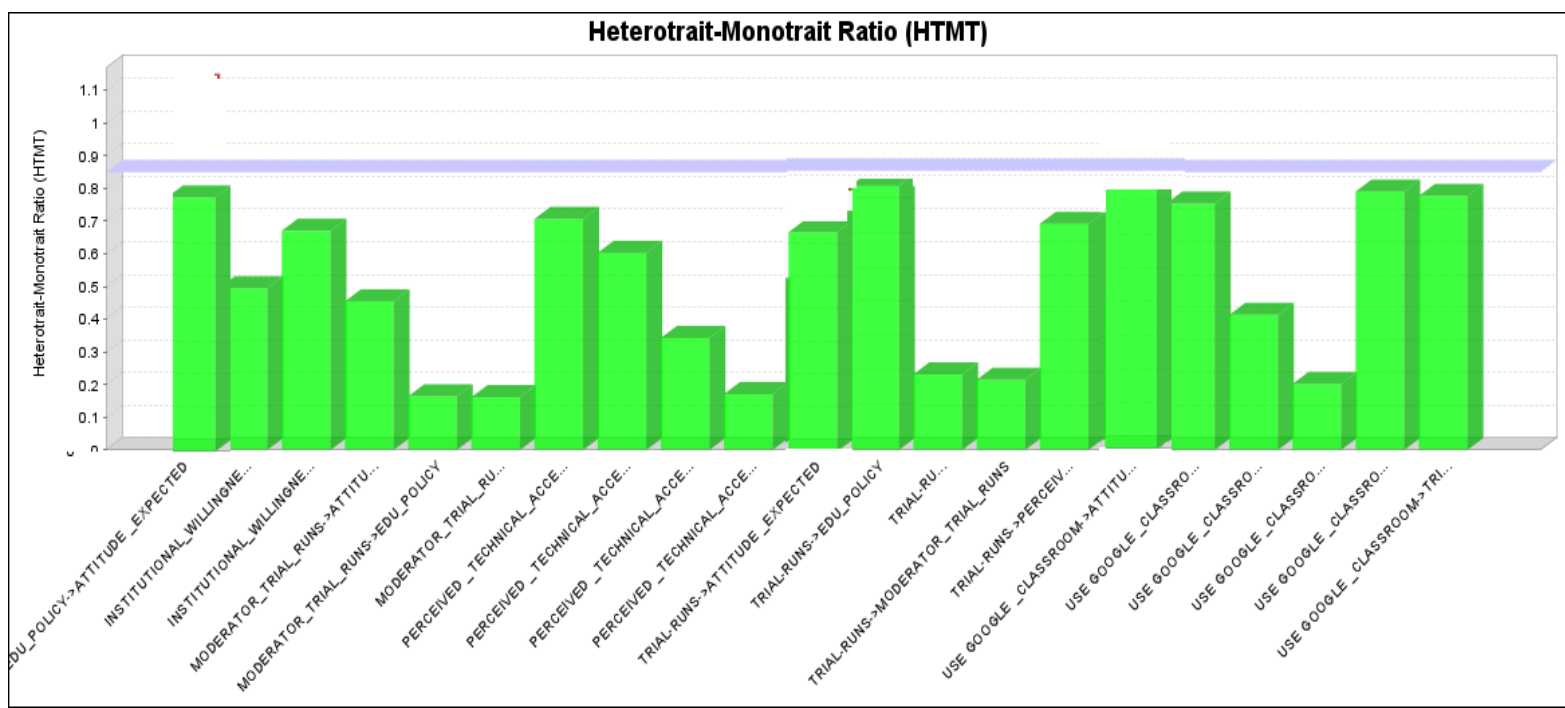

Figure 2. Heterotrait-monotrait ratio of correlation.

The Cronbach's alpha ranges from 0.742 to 0.908 , the rho_A ranges from 0.724 to 0.911 , the composite reliability (CR) ranges from 0.744 to 0.932 , and the average variance explained (AVE) ranges from 0.533 to 0.733 . Nevertheless, the value of 1.000 noted in the moderator_trial_runs and edu_policy is the default setting of the moderating effect property estimate of SmartPLS 3.0 (Ringle et al., 2018; Memon et al., 2019). Table 2 depicts the measurement construction for reliability and validity in structural equation modelling.

Table 2. Measurement construction reliability and validity.

\begin{tabular}{|l|c|c|c|c|}
\hline Matrix & $\begin{array}{l}\text { Cronbach's } \\
\text { alpha }\end{array}$ & Rho_A & Composite reliability & A V E \\
\hline Attitude_Expected & 0.788 & 0.724 & 0.744 & 0.533 \\
\hline Edu_Policy & 0.781 & 0.789 & 0.873 & 0.696 \\
\hline Institutional_Willingness & 0.910 & 0.900 & 0.789 & 0.556 \\
\hline Moderator_Trial_Runs & 1.000 & 1.000 & 1.000 & - \\
\hline Edu_Policy* & - & 1.000 & 000 \\
\hline Perceived_Technical_Access & 0.742 & 0.750 & 0.854 & 0.662 \\
\hline Trail_Runs & 0.908 & 0.911 & 0.932 & 0.733 \\
\hline UseGoogle_Classroom & 0.894 & 0.899 & 0.921 & 0.702 \\
\hline
\end{tabular}

Furthermore, the SmartPLS 3.0 algorithm report revealed that all of the model's dimensions have acceptable discriminant validity and are reliable for bootstrapping towards the final structural equation modelling of this study.

\subsection{Structural model outcomes}

The structural variance tests were performed after a good fit of the measurement model was established. A structural equation modelling (SEM) approach was used in this study to evaluate the moderating impact of trial runs as well as the influence of perceived purposefulness in the link between educational policy and the use of Google Classroom. The structure of the path diagram (Figure 4 and Table 2) illustrates the connections between the dimensions based on the tested assumptions. In this way, it is possible to visualize both the direct and indirect effect of one factor on others. The significance of the hypotheses is justified by $t$-statistics (usually $\leq \pm 1.96$ ) and the computed $p$-value (usually $\leq 0.05$ ). The 
results showed that all the fit indexes examined in the case of the hypothesized structural model were significant according to quality index values (Solomon et al., 2014; Ringle et al., 2018; Memon et al., 2019; Agboola \& Oluyinka, 2019).

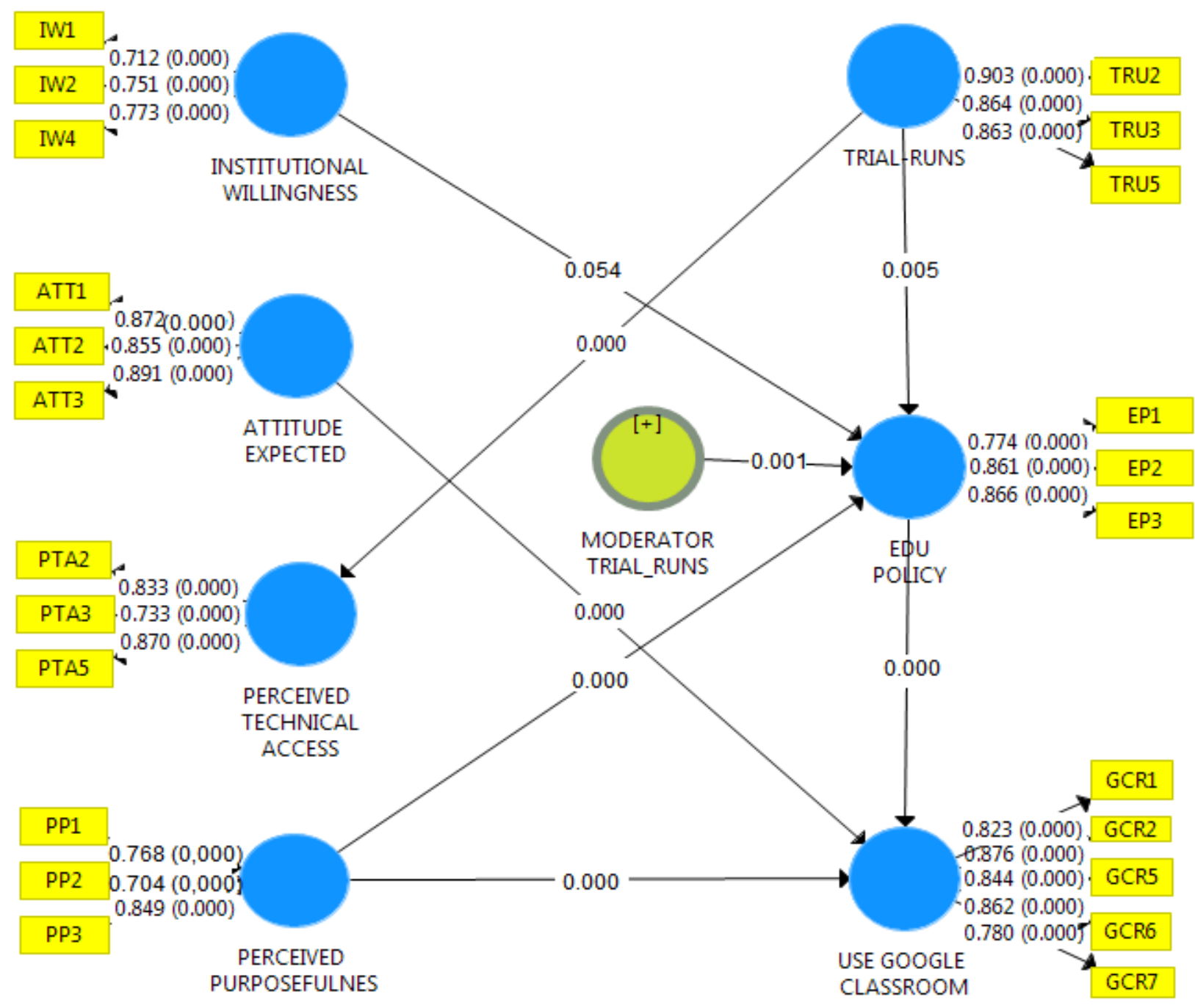

Figure 3. Trial runs and purposefulness effect of GCR acceptance structured model.

Table 3 illustrates the hypothetical and path coefficients of the study.

Table 3. Hypothetical path coefficients.

\begin{tabular}{|l|l|l|l|l|l|l|l|}
\hline \multicolumn{2}{|l|}{ Hypothesized paths } & Mean & SError & $T$-stat & $P$-value \\
\hline H1 & Attitude Expected & $\rightarrow$ & Use Google Classroom & 0.272 & 0.116 & 2.787 & 0.005 \\
\hline H2 & Educational Policy & $\rightarrow$ & Use Google Classroom & 0.404 & 0.146 & 5.941 & 0.000 \\
\hline H3 & $\begin{array}{l}\text { Institutional } \\
\text { willingness }\end{array}$ & $\rightarrow$ & Educational Policy & 0.069 & 0.079 & 1.923 & 0.054 \\
\hline H4 & Moderator-TRuns & $\rightarrow$ & Educational Policy & 0.412 & 0.114 & 3.282 & 0.001 \\
\hline H5 & $\begin{array}{l}\text { Perceived } \\
\text { Purposefulness }\end{array}$ & $\rightarrow$ & Educational Policy & 0.611 & 0.092 & 6.615 & 0.000 \\
\hline
\end{tabular}




\begin{tabular}{|l|l|l|l|l|l|l|l|}
\hline H6 & $\begin{array}{l}\text { Perceived } \\
\text { Purposefulness }\end{array}$ & $\rightarrow$ & Use Google Classroom & 0.422 & 0.096 & 4.088 & 0.000 \\
\hline H7 & Trial Runs & $\longrightarrow$ & Educational Policy & 0.303 & 0.113 & 2.803 & 0.005 \\
\hline H8 & Trial Runs & $\rightarrow$ & $\begin{array}{l}\text { Perceived Technological } \\
\text { Access }\end{array}$ & 0.579 & 0.891 & 9.769 & 0.000 \\
\hline
\end{tabular}

Table 3 indicates that all the stated hypotheses are supported from values $<0.00$ to $<0.054$. For H1: Attitude is expected to influence GCR acceptance; this is supported at $t=2.787 ; p<0.005$. This indicates that the attitude of the students and teachers investigated revealed that acceptance of Google Classroom is influenced by the expected attitude of the users. For H2: Educational policy may influence acceptance of GCR; it is supported at $t=5.941 ; p<0.000$, which is suggested as one of the most significant findings of this study; this implies that a clear decision with respect to a learning management system such as Google Classroom, acceptance can be influenced by the CHED. For H3: Institutional willingness may influence educational policy to accept GCR among the HEI; it is partially supported at $t=1.923 ; p<0.054$. For H4: Trialability of GCR may have a moderating effect on educational policy; it is also supported at $t=3.282$; $p<0.001$. Furthermore, H5: Perceived purposefulness may influence educational policy; this has been found to be highly supported $(t=6.615 ; p<0.000)$ as well as H6: Purposefulness may influence Google Classroom acceptance $(t=4.088 ; p<0.000)$. For H7: Trialability of GCR may influence educational policy among the users; it is supported at $t=2.803 ; p<0.005$. Nevertheless, the hypothesis H8: Trialability of GCR may influence technical access, has been found to be the most influential assumption in this study $(t=9.769 ; p<0.000)$. This is highly considered among the public HEI in Region III, Philippines.

Trialability moderating effects in the relationship between educational policy and use of Google Classroom were based on a two-stage calculation method. Product term generation which was based on standardized default was adopted (Hair et al., 2017; Henseler et al., 2012). The moderating effects of trialability and purposefulness on GCR to educational policy revealed an explained variance of 0.858 , or $86 \%$ of the variance. This was generated and reported based on the SmartPLS 3.0 default. Moreover, the expected attitude, perceived purposefulness, and educational policy on use of Google Classroom indicated 95\% variance. Details are provided in Figure 4 and Table 3. In Table 4, the total effects of trialability and purposefulness by rank are shown.

Table 4. Total effects of trialability and purposefulness by rank.

\begin{tabular}{|l|l|c|c|c|}
\hline No. & Hypothetical paths & T-statistics & Supported/Not & Rank \\
\hline 1 & Trial runs -> educational policy & 11.667 & Supported & Top 1 \\
\hline 2 & $\begin{array}{l}\text { Perceived purposefulness -> use Google } \\
\text { Classroom }\end{array}$ & 8.793 & Supported & Top 3 \\
\hline 3 & Attitude expected -> use Google Classroom & 3.552 & Supported & Top 6 \\
\hline 4 & Educational policy -> use Google Classroom & 8.743 & Supported & Top 4 \\
\hline 5 & Institutional willingness -> educational policy & 1.987 & Partially & supported \\
\hline 6 & Moderator t-runs -> educational policy & 3.414 & Supported & Top 7 \\
\hline 7 & $\begin{array}{l}\text { Perceived purposefulness -> educational } \\
\text { policy }\end{array}$ & 6.946 & Supported & Top 5 \\
\hline 8 & Trial runs -> perceived technical access & 11.133 & Supported & Top 2 \\
\hline
\end{tabular}




\section{Discussion and Implications}

The hypotheses raised in this study had all been supported, which proves that Google Classroom is an appropriate platform for colleges and universities. Influenced by two most important factors, namely trialability and purposefulness, Google Classroom has been accepted and adopted in higher institutions of learning.

The study described some relationships which assessed willingness to use GCR. It examined the impact of purposefulness, perception of technological access, and the moderating effects of trial runs in line with the CHED's advisory to use online learning modalities. Supported by the studies of Toquero (2020) and Rahmad et al. (2019), the findings justified the fact that the acceptance and adoption of Google Classroom depends on the positive relationship and agreement between public higher education institutions and the consideration of the educational board on distance learning.

The construct has a positive overall correlation with the use of GCR, educational policy, anticipated attitude and institutional willingness. According to the statistical explanations for the target objectives, a trial run on the technical access path is considered the most significant in this analysis. In addition, findings indicate that the trial runs play a moderating role in the policies and aims of the education board allowing GCR to be used by the public HEI. Studies have found support for these results (Abd Manan \& Hanafi, 2019; Albashtawi \& Al Bataineh, 2020).

Moreover, the findings of this study are expected to guide students to concentrate on the skills required to be developed, resulting in effective learning during and after the outbreak of COVID19. Effective use and adoption of GCR establishes an academic learning atmosphere where both teachers and students encourage acceptance of the system.

The moderating effect analysis indicates that total effect exists among the suggested factors to use Google Classroom. It distinguishes the total moderating effects of trialability on educational policy to use Google Classroom. This means that a trial of the learning system called Google Classroom should be considered in Philippine higher education institutions during the COVID19 pandemic. The said technology could serve as a point of reference to substantially contribute to the current educational system.

\section{Conclusions and Recommendations}

The present study adopted the TAM model and reviewed studies related to the acceptance of technology in education. A structural equation model with the specification of complete bootstrapped, regression and moderating effects and built-in SmartPLS 3.0 for analysis was used to achieve the objectives of the study. However, trial runs were adopted as moderating factors. This was done considering that there were setbacks on perceived technical access, attitude, educational policy, institutional willingness and perceived purposefulness towards GCR among the justified predictable constructs investigated based on 5000 bootstrapped settings samples.

The findings of the study reveal that seven of the hypotheses raised were highly supported and only one was partially supported. This proves that Google Classroom is an appropriate platform for colleges and universities. Influenced by two most important factors, namely trialability and purposefulness, Google Classroom has been accepted and adopted in higher institutions of learning.

Hence, the following conclusions can be made: Google Classroom has been found to be very effective; thus, it has been accepted by Filipino students and teachers in the present study, trialability and 
purposefulness are two great factors that helped in the acceptance and adoption of Google Classroom in colleges and universities. Professional development programmes such as workshops and seminars are needed by the teachers and the learners. Furthermore, Google Classroom is used in other countries. Its effectiveness has been supported in the studies of Alajmi et al. (2018) and Washington (2019), On the part of tools, SmartPLS 3.0 has been found to be very helpful in analysing the moderation of a specified factor, and internet connection is a problem among teachers and learners.

Nevertheless, based on the conclusions given, the following are recommended: the education board led by the CHED should consider the adoption of GCR and public HEI should support users with an internet connection and further promote technology acceptance. In addition, professional development programmes need to be arranged for teachers to encourage the use of GCR for learning activities outside the classroom. The generalizability of our findings may be confirmed by performing another study, which is strongly recommended. Meanwhile, future researchers may need to double-check the research findings and look into the influence of other factors such as expected attitude or educational policy in the context of the moderator. Institutions should be prepared to identify strategies for promoting and inspiring student engagement as well as understanding the value of learning skills in GCR. More time should be allocated for slow students to finish their homework due to a low level of connectivity as indicated in the research concerns. Students who are unable to have full access to technology at home should be given alternative activities in performing their assigned school tasks.

\section{Additional Information and Declarations}

Acknowledgements: We would like to express our heartfelt thanks to all the participants for having spared their time and effort in answering the questionnaires.

Conflict of Interests: The authors declare no conflict of interest.

Author Contributions: S.O.: conceptualization, data curation, formal analysis, software, investigation, project administration, supervision, validation, writing - original draft. M.C.: funding acquisition, methodology, resources, visualization, writing - review and editing.

Data Availability: The data that support the findings of this study are available from the corresponding author. Attached herein is the link to questionnaire: https://forms.gle/4opnfR6]ZNKwbfDS6

\section{References}

Abazi-Bexheti, L., Kadriu, A., Apostolova-Trpkovska, M., Jajaga, E., \& Abazi-Alili, H. (2018). LMS solution: Evidence of Google Classroom usage in higher education. Business Systems Research: International Journal of the Society for Advancing Innovation and Research in Economy, 9(1), 31-43.

Abd Manan, N. Z., \& Hanafi, H. F. (2019). Google Classroom: Student's acceptance using UTAUT Model. Journal of Applied Arts, 1(1), 64-72. https://journal.scientiaca.org/index.php/Jappa/article/view/40

Abdullah, F., \& Ward, R. (2016). Developing a General Extended Technology Acceptance Model for E-Learning (GETAMEL) by analysing commonly used external factors. Computers in human behavior, 56, 238-256. https://doi.org/10.1016/j.chb.2015.11.036

Agboola, O. P., \& Oluyinka, S. (2019). Perceptions of ethnic residents' satisfaction: a quest towards the sustainable development of public space in Nigeria. International Journal of Happiness and Development, 5(1), 66-82. https://doi.org/10.1504/IJHD.2019.098050

Aguinis, H., Edwards, J. R., \& Bradley, K. J. (2017). Improving our understanding of moderation and mediation in strategic management research. Organizational Research Methods, 20(4), 665-685 https://doi.org/10.1177/1094428115627498

Musibau, A.A., Oluyinka, S., \& Long, C.S. (2011). The relationship between strategic planning and the effectiveness of marketing operations. International Journal of innovation management and Technology, 2(5), 390-396.

Ajagbe, M. A., Long, C. S., \& Solomon, O. (2014). The impact of sales promotion and product branding on company performance : A case study of AllCO insurance Nigerian PLC. Procedia - Social and Behavioral Sciences, 129, $164-171$. https://doi.org/10.1016/j.sbspro.2014.03.662 
Alajmi, Q., Arshah, R. A., Kamaludin, A., \& Al-Sharafi, M. A. (2018). Current state of cloud-based e-learning adoption: Results from Gulf Cooperation Council's Higher Education Institutions. In 2018 IEEE 9th Annual Information Technology, Electronics and Mobile Communication Conference (IEMCON), (pp. 569-575). IEEE https://doi.org/10.1109/IEMCON.2018.8614772

Albashtawi, A., \& Al Bataineh, K. (2020). The effectiveness of Google Classroom among EFL students in Jordan: An innovative teaching and learning online platform. International Journal of Emerging Technologies in Learning, 15(11), 7888.

Al-Maroof, R. A. S., \& Al-Emran, M. (2018). Students' acceptance of Google Classroom: An exploratory study using PLS-SEM approach. International Journal of Emerging Technologies in Learning, 13(6), 112-123. https://www.learntechlib.org/p/183928/

Ayodele, S. O., Oga, O. E., Bundot, Y. G., \& Ogbari, M. E. (2016). Role of power supply towards e-learning acceptance: VBSEM-AMOS. In 2016 6th International Conference on Information Communication and Management (ICICM) (pp. 151155). IEEE. https://doi.org/10.1109/INFOCOMAN.2016.7784233

Ayodele, S., Endozo, A., \& Ogbari, M. E. (2018). A study on factors hindering online learning acceptance in developing countries. In Proceedings of the 10th International Conference on Education Technology and Computers (pp. 254-258). https://doi.org/10.1145/3290511.3290533

Bayarmaa, N., \& Lee, A. (2018). Study on the application of Google Classroom for problem-based learning. Journal of the Korea Academia-Industrial, 10, 81-87. https://doi.org/10.5762/KAIS.2018.19.7.81

Calma, R. R. \& Oluyinka, S. A. (2020). Awareness and implementation of corporate social responsibility among lumber business in Central Luzon, Philippines. Harvest, 16(1). http://ejournals.ph/form/cite.php?id=15717

Charnes, N., \& Boot, W. R. (2016). Technology, gaming, and social networking. In Handbook of the psychology of aging (pp. 389-407). Elsevier. https://doi.org/10.1016/B978-0-12-411469-2.00020-0

Dana, N. F., \& Yendol-Hoppey, D. (2019). The reflective educator's guide to classroom research: Learning to teach and teaching to learn through practitioner inquiry. Corwin.

Davis, F. D., Bagozzi, R. P., \& Warshaw, P. R. (1989). User acceptance of computer technology: a comparison of two theoretical models. Management Science, 35(8), 982-1003. https://doi.org/10.1287/mnsc.35.8.982

Dayrit, J. S., \& Lacap, J. P. (2020). The Influence of Work life balance on Employee engagement among workers in Pampanga. Philippines: A Structural Equation Modelling Approach. International Journal of Psychosocial Rehabilitation, 24(4), 3095-3112. https://doi.org/10.37200/IJPR/V24I4/PR201420

De Campos Filho, A. S., de Souza Fantini, W., Ciriaco, M. A., dos Santos, J., Moreira, F., \& Gomes, A. S. (2019). Health student using Google Classroom: Satisfaction analysis. In International Workshop on Learning Technology for Education in Cloud (pp. 58-66). Springer. https://doi.org/10.1007/978-3-030-20798-4 6

De Vera III, J. P. E. (2020). Guidelines for the prevention, control, and mitigation of the spread of coronavirus disease 2019 (Covid-19) in Higher Education Institutions (Heis), Ched Covid Advisory No. 6. https://ched.gov.ph/wpcontent/uploads/CHED-COVID-19-Advisory-No.-6.pdf

Duan, Y., He, Q., Feng, W., Li, D., \& Fu, Z. (2010). A study on e-learning take-up intention from an innovation adoption perspective : A case in China. Computers \& Education, 55(1), 237-246. https://doi.org/10.1016/j.compedu.2010.01.009

Endozo, A. N., \& Solomon, O. A. (2019). Teachers'perceptions in enhancing the performance of low-skilled students. Theoretical \& Applied Science (2), 244-251. https://doi.org/10.15863/TAS.2019.02.70.21

Endozo, A. N., Oluyinka, S., \& Daenos, R. G. (2019). Teachers' experiences towards usage of Learning Management System: CANVAS. In ICETC 2019: Proceedings of the 2019 11th International Conference on Education Technology and Computers (pp. 91-95). ACM. https://doi.org/10.1145/3369255.3369257

Ewing, L. A., \& Cooper, H. B. (2021). Technology-enabled remote learning during COVID-19 : Perspectives of Australian teachers, students and parents. Technology, Pedagogy and Education, 30(1), 41-57. https://doi.org/10.1080/1475939X.2020.1868562

Ezekiel, E.I., \& Oluyinka, S. (2020). Acceptance of Human Resource Information Technology in Nigeria. International Scientific Journal Theoretical \& Applied Science, 83(3), 246-256.

Fenton, W. (2017). Google classroom not in the college classroom. Inside Higher Ed. https://www.insidehighered.com/digitallearning/article/2017/06/21/google-classroom-not-college-classroom

Fornell, C., \& Larcker, D. F. (1981). Evaluating structural equation models with unobservable variables and measurement error. Journal of marketing research, 18(1), 39-50. https://doi.org/10.2307/3151312

Francom, G. M., Schwan, A., \& Nuatomue, J. N. (2021). Comparing Google classroom and D2L Brightspace using the technology acceptance model. TechTrends, 65(1), 111-119. https://doi.org/10.1007/s11528-020-00533-0

Froese, F. J., Peltokorpi, V., Varma, A., \& Hitotsuyanagi-Hansel, A. (2018). Merit-based rewards, job satisfaction and voluntary turnover : Moderating effects of employee demographic characteristics. British Journal of Management, 1-14. https://doi.org/10.1111/1467-8551.12283

Gardner, R. G., Harris, T. B., Li, N., Kirkman, B. L., \& Mathieu, J. E. (2017). Understanding "It Depends" in organizational research: A theory-based taxonomy, review, and future research agenda concerning interactive and quadratic relationships. Organizational Research Methods, 20(4), 610-638. https://doi.org/10.1177/1094428117708856

Granić, A., \& Marangunić, N. (2019). Technology acceptance model in educational context: A systematic literature review. British Journal of Educational Technology, 50(5), 2572-2593. https://doi.org/10.1111/bjet.12864 
Gutierrez, A., Boukrami, E., \& Lumsden, R. (2015). Technological, organisational and environmental factors influencing managers' decision to adopt cloud computing in the UK. Journal of Enterprise Information Management, 28(6), 788-807. https://doi.org/10.1108/JEIM-01-2015-0001

Hair, J. F., Hult, G. T. M., Ringle, C. M., \& Sarstedt, M. (2017). A primer on partial least squares structural equation modeling. Sage.

Hair, J. F., Risher, J. J., Sarstedt, M., \& Ringle, C. M. (2019). When to use and how to report the results of PLS SEM. European Business Review, 31(1), 2-24. https://doi.org/10.1108/EBR-11-2018-0203

Henseler, J., Fassott, G., Dijkstra, T., \& Wilson, B. 2012. Analyzing quadratic effects of formative constructs by means of variance-based structural equation modelling. European Journal of Information Systems, 21(1): 99-112. https://doi.org/10.1057/ejis.2011.36

Hussein, Z. (2017). Leading to intention: The role of attitude in relation to technology acceptance model in e-learning. Procedia Computer Science, 105, 159-164. https://doi.org/10.1016/j.procs.2017.01.196

Ivanovic, Z., \& Milenkovski, A. (2019). Importance of New Approaches in Education for Higher Education Institutions. UTMS Journal of Economics, 10(1), 67-76. https://ideas.repec.org/a/ris/utmsje/0261.html

Kaewsaiha, P. (2019). Usability of the Learning Management System and Choices of Alternative. In The International Conference on Education, Psychology, and Social Sciences (ICEPS), (pp. 252-259). Tokyo University of Science.

Karkar, A. J., Fatlawi, H. K., \& Al-Jobouri, A. A. (2020). Highlighting e-learning adoption challenges using data analysis techniques: University of Kufa as a case study. Electronic Journal of e-Learning, 18(2), 136-149.

Kumar, J.A., Bervell, B. Osman, S. (2020). Google Classroom: Insights from Malaysian higher education students' and instructors' experiences. Education and Information Technologies, 25(5), 4175-4195. https://doi.org/10.1007/s10639-020$\underline{10163-x}$

Lai, J. W. M., \& Bower, M. (2019). How is the use of technology in education evaluated? A systematic review. Computers \& Education, 133, 27-42. https://doi.org/10.1016/i.compedu.2019.01.010

Lazar, I. M., Panisoara, G., \& Panisoara, I. O. (2020). Digital technology adoption scale in the blended learning context in higher education: Development, validation and testing of a specific tool. PloS One, 15(7), e0235957. https://doi.org/10.1371/journal.pone.0235957

Lee, D. (2019). The convergent, discriminant, and nomological validity of the Depression Anxiety Stress Scales-21 (DASS-21). Journal of affective disorders, 259, 136-142. https://doi.org/10.1016/j.jad.2019.06.036

Leuteritz, J. P., Navarro, J., \& Berger, R. (2019). Validation of the group tasks uncertainty model (MITAG) in a German sample. PloS One, 14(11), e0224485. https://doi.org/10.1371/journal.pone.0224485

Macedo, I. M. (2017). Predicting the acceptance and use of information and communication technology by older adults: An empirical examination of the revised UTAUT2. Computers in Human Behavior, 75, 935-948. https://doi.org/10.1016/j.chb.2017.06.013

Memon, M. A., Cheah, J. H., Ramayah, T., Ting, H., Chuah, F., \& Cham, T. H. (2019). Moderation analysis: issues and guidelines. Journal of Applied Structural Equation Modeling, 3(1), 1-11.

Memon, M. A., Ting, H., Ramayah, T., Chuah, F., \& Cheah, J. H. (2017). A review of the methodological misconceptions and guidelines related to the application of structural equation modeling: A Malaysian scenario. Journal of Applied Structural Equation Modeling, 1(1), i-xiii.

Mohr, C. (2021). Google apps for education now has more than 50 million users. https://www.teachthought.com/education/google-apps-for-education-now-has-more-than-50-million-users/

Mousa, A. H., Mousa, S. H., Mousa, S. H., \& Obaid, H. A. (2020). Advance acceptance status model for E-learning based on university academics and students. In IOP Conference Series: Materials Science and Engineering (Vol. 671, No. 1, p. 012031). IOP Publishing. https://doi.org/10.1088/1757-899X/671/1/012031

Ngafeeson, M. N., \& Sun, J. (2015). The effects of technology innovativeness and system exposure on student acceptance of e-textbooks. Journal of Information Technology Education: Research, 14, 55-71. https://doi.org/10.28945/2101

O'Bannon, B. W., \& Thomas, K. M. (2015). Mobile phones in the classroom: Preservice teachers answer the call. Computers \& Education, 85, 110-122. https://www.learntechlib.org/p/201811/

Oluyinka, S. A. (2016). The role of trust as a mediator in the relationship between technology factors and intention to accept internet banking in Nigeria. Doctoral dissertation. Universiti Tun Hussein Onn Malaysia. https://core.ac.uk/download/pdf/159127878.pdf

Oluyinka, S. A., Endozo, A. N., \& Calma, R. R. (2018, October). A study on the acceptance of internet banking. In Proceedings of the 10th International Conference on Education Technology and Computers (pp. 374-378). ACM. https://doi.org/10.1145/3290511.3290531

Oluyinka, S., Daenos, R., Cusipag N.M., \& Lasisi, A. (2021). Google Classroom's Quadratic Purposefulness and Moderation During Covid-19 Spread. Turkish Journal of Computer and Mathematics Education, 12(11), 3008-3019. https://turcomat.org/index.php/turkbilmat/article/view/6339

Oluyinka, S., Shamsuddin, A., \& Wahab, E. (2015). Regions of Trust to Technological Know-how Structured for Banking Customers. Asian Journal of Applied Sciences, 3(4), 679-691.

Oluyinka, S., Shamsuddin, A., Wahab, E., Ajagbe, M. A., \& Enegbuma, W. I. (2013). A study of electronic commerce adoption factors in Nigeria. International Journal of Information Systems and Change Management, 6(4), $293-315$. https://doi.org/10.1504/IJISCM.2013.060974 
Pan, X. (2020). Technology Acceptance, Technological Self-Efficacy, and Attitude Toward Technology-Based Self-Directed Learning: Learning Motivation as a Mediator. Frontiers in Psychology, 11. https://doi.org/10.3389/fpsyg.2020.564294

Pandl, K. D., Teigeler, H., Lins, S., Thiebes, S., \& Sunyaev, A. (2021). Drivers and inhibitors for organizations' intention to adopt artificial intelligence as a service. In Proceedings of the 54th Hawaii International Conference on System Sciences (pp. 1769-1778). https://doi.org/10.24251/HICSS.2021.215

Pangilinan, R. R. (2020). Study on Copyright Awareness among College Students. International Journal of Knowledge Engineering, 35-39. https://doi.org/10.18178/ijke.2020.6.1.129

Perdana, I., Saragi, R. E. S., \& Aribowo, E. K. (2020). Persepsi Siswa terhadap Pemanfaatan Media Kahoot dalam Pembelajaran Bahasa Indonesia. Kwangsan, 8(2), 332460. https://doi.org/10.31800/jtp.kw.v8n2.p290--306

Rahmad, R., Wirda, M. A., Berutu, N., Lumbantoruan, W., \& Sintong, M. (2019). Google Classroom implementation in Indonesian higher education. Journal of Physics: Conference Series,1175(1), 012153. https://doi.org/10.1088/1742 $\underline{6596 / 1175 / 1 / 012153}$

Rai, S. K., Ramamritham, K., \& Jana, A. (2020). Identifying factors affecting the acceptance of government to government system in developing nations-empirical evidence from Nepal. Transforming Government: People, Process and Policy, 14(2), 283-303. https://doi.org/10.1108/TG-05-2019-0035

Ramírez-Correa, P. E., Arenas-Gaitán, J., \& Rondán-Cataluña, F. J. (2015). Gender and acceptance of e-learning: a multigroup analysis based on a structural equation model among college students in Chile and Spain. PloS One, 10(10), e0140460. https://doi.org/10.1371/journal.pone.0140460

Ringle, C. M., Sarstedt, M., Mitchell, R., \& Gudergan, S. P. (2018). Partial least squares structural equation modeling in HRM research. The International Journal of Human Resource Management, 31(12), 1-27. https://doi.org/10.1080/09585192.2017.1416655

Robinson, C. (2017). Technology tools for a paperless classroom. Science Scope, 41(3), 18-21. https://www.jstor.org/stable/26387216

Rogers, E. M. (2004). A Prospective and Retrospective Look at the Diffusion Model. Journal of health communication, 9(S1), 13-19. https://doi.org/10.1080/10810730490271449

Roman, R. G., Spencer, C. P., Trobada, F. P., Gaton, C. K. G., Solomon, A. O., Cuenco, H. O., \& Daenos, R. C. (2020). A study on the utilization of e-resources among college students. International Journal of Knowledge Engineering, 6(1), 2429. https://doi.org/10.18178/ijke.2020.6.1.127

Saloviita T. (2015). Measuring pre-service teachers' attitudes towards inclusive education: Psychometric properties of the TAIS scale. Teaching and Teacher Education. 52, 66-72. https://doi.org/10.1016/j.tate.2015.09.003

Sarstedt, M., \& Cheah, J. H. (2019). Partial least squares structural equation modeling using SmartPLS: A software review. Journal of Marketing Analytics, 7(3), 196-202. https://doi.org/10.1057/s41270-019-00058-3

Sibuea, T. F. (2018). Students'perceptions On The Use Of Google Classroom To Support Blended Learning For The Pengantar Linguistik Umum Course. Lingua: Jurnal IImiah, 14(2), 49-63. https://doi.org/10.35962/lingua.v14i2.45

Singh, A., Mangalaraj, G., \& Taneja, A. (2010). Bolstering teaching through online tools. Journal of Information Systems Education, 21(3), 299-311.

Siswanto, T., Shofiati, R., \& Hartini, H. (2018). Acceptance and utilization of technology (UTAUT) as a method of technology acceptance model of mitigation disaster website. In IOP Conference Series: Earth and Environmental Science (Vol.106, No.1, 012011). IOP Publishing. https://doi.org/10.1088/1755-1315/106/1/012011

Solomon, O., Alina, S., Eta, W., \& Ajagbe, M. A. (2014). Internet banking adoption in Nigeria: A literature review. In Computer, Intelligent Computing and Education Technology (pp.168-175). CRC Press. https://doi.org/10.1201/9781315760810

Sukmawati, S., \& Nensia, N. (2019). The role of Google Classroom in ELT. International Journal for Educational and Vocational Studies, 1(2), 142-145. https://doi.org/10.29103/ijevs.v1i2.1526

Tom, A. M., Virgiyanti, W., \& Rozaini, W. (2019). Understanding the determinants of infrastructure as a service-based elearning adoption using an integrated TOE-DOI Model: A Nigerian perspective. In 2019 6th International Conference on Research and Innovation in Information Systems (ICRIIS) (pp. 1-6). IEEE. https://doi.org/10.1109/ICRIIS48246.2019.9073418

Toquero, C. M. (2020). Challenges and opportunities for higher education amid the COVID-19 pandemic: The Philippine context. Pedagogical Research, 5(4), em0063. https://doi.org/10.29333/pr/7947

Türel, Y. K. (2011). An interactive whiteboard student survey: Development, validity and reliability. Computers \& Education, 57(4), 2441-2450. https://doi.org/10.1016/j.compedu.2011.07.005

UNESCO. (2020a). 290 million students out of school due to COVID-19: UNESCO releases first global numbers and mobilizes response. UNESCO. https://en.unesco.org/news/290-million-students-out-school-due-covid-19-unesco-releases-firstglobal-numbers-and-mobilizes

UNESCO. (2020b). COVID-19 Educational disruption and response. https://en.unesco.org/news/covid-19-educationaldisruption-and-response

Vaughan, N. D. (2010). Blended learning. In An introduction to distance education: Understanding teaching and learning in a new era. Taylor \& Francis.

Waheed, M., Kaur, K., Ain, N., \& Sanni, S. A. (2015). Emotional attachment and multidimensional self-efficacy : Extension of innovation diffusion theory in the context of eBook reader. Behaviour \& Information Technology, 34(12), 1147-1159. https://doi.org/10.1080/0144929X.2015.1004648 
Washington, G. Y. (2019). The learning management system matters in face-to-face higher education courses. Journal of Educational Technology Systems, 48(2), 255-275. https://doi.org/10.1177/0047239519874037

Webster, C. A., Caputi, P., Perreault, M., Doan, R., Doutis, P., \& Weaver, R. G. (2013). Elementary classroom teachers' adoption of physical activity promotion in the context of a statewide policy: An innovation diffusion and socio-ecologic perspective. Journal of Teaching in Physical Education, 32(4), 419-440.

Yalung, H. A., Tuliao, D. L., Gabriel, P. R. M., Oluyinka, S. A., \& Gil, M. (2020). Use of social media platforms in promoting the academic library services of City College of Angeles among students. International Journal of Information and Education Technology, 10(6). https://doi.org/10.18178/ijiet.2020.10.6.1411

Editorial record: The article has been peer-reviewed. First submission received on 15 April 2021. Revisions received on 24 May 2021, 29 June 2021 and 14 July 2021. Accepted for publication on 15 July 2021. The editors coordinating the peer-review of this manuscript were Chiew Kang Leng (D) and Zdenek Smutny (D. The editor in charge of approving this manuscript for publication was Zdenek Smutny.

Special Issue: Inspiring Technologies for Digital Inclusivity. Selected papers from the $12^{\text {th }}$ International Conference on Information Technology in Asia (CITA'21).

Acta Informatica Pragensia is published by Prague University of Economics and Business, Czech Republic.

ISSN: 1805-4951 